\title{
Kiran Desai's Hullabaloo in the Guava Orchard: A Critique
}

\author{
Avinash L. Pandhare \\ Assistant Professor \\ Department of English \\ Anand Niketan College \\ Anandwan-Warora, Chandrapur (MS), India \\ avinash.pandhare265@gmail.com
}

\begin{abstract}
In Hullabaloo in the Guava Orchard, her debut novel, Kiran Desai has experimented in the making of a comic fable. She presents a hilarious story of life, love, and family relationships - simultaneously capturing the vivid culture of the Indian subcontinent and the universal intricacies of human experience. The story is set in a small Indian but fictitious town called Shahkot. Sampath is the protagonist who belongs to a middle class family. After experiencing drastic boredom in his life, Sampath decides to spend his life in trees. And then after, the story reveals its real mood. At a deeper level, the novel displays the theme of alienation, magic realism, rebellion, etc. Desai is a masterful dialogue writer, and she uses this skill to great effect in Hullabaloo in the Guava Orchard. She infuses the dialogue with local idioms and paints a vivid portrait of life in a small city in India. With a clear objective of writing a comic satire, she also makes a satirical attack against the creation of gurus in Indian society.
\end{abstract}

Keywords: Kiran Desai, Magic Realism, Alienation, Rebellion, Comic Satire 
In Hullabaloo in the Guava Orchard, her debut novel, Kiran Desai has experimented in the making of a comic fable. She presents a hilarious story of life, love, and family relationships - simultaneously capturing the vivid culture of the Indian subcontinent and the universal intricacies of human experience. It is a cheerful literary work resembling to folktale. If read thoroughly, one can also detect elements of comic satire in the novel. In her interview Kiran Desai told that the plot of the novel is inspired by a real event. Sampath Chawla is the central character in story of Hullabaloo in the Guava Orchard. He was "born in a time of drought into a family not quite like other families, in a town not quite like other towns" ("Book Summary"). The story is set in a small Indian but fictitious town called Shahkot. The scene of the story does not get shifted from this place throughout the novel. This is quite different from Desai's Booker Prize winning novel The Inheritance of Loss (2006), where story switches between India and the USA. Sampath was born when monsoon finally came to the village of Shahkot after months and months of terrible drought. Immediately after his birth as the rain falls, a plane dropped down Red Cross supplies. The villagers greeted his birth with joy and happiness. This was, according to the villagers, good fortune for the village and they told each other that the work had taken notice of his birth. The neighbours told Kulfi, "Look! Even people in Sweden have remembered to send a birthday present" (Desai 12). They named him 'Sampath' meaning good fortune. Only his mother, Kulfi, was quiet and silent giving no enthusiastic reaction. The boy, however, does not fulfill the expectations created on his birth. Sampath's life was very strange. He had interest in nothing. His performance at school was very poor. Somehow he managed to pass his examinations. His father managed to get a job for him. He got appointed in the local post office as a clerk. But Sampath's course of life did not change. It began with failure and continued on the same path. He did nothing except spending time in shops and tea stalls of Shahkot, and in day-dreaming and singing. Sunita Sinha remarks that Hullabaloo in the 
Guava Orchard is a story of an "ambitionless son of the middle class family who wants to escape the looming responsibilities of his adult life" (xviii). Sampath lacks interest in everything and this deeply offends his father. His father tells the family about uncertainty of Sampath's prospects:

Ever since he [Sampath] was born, this boy has been progressing steadily in the wrong direction. Instead of trying to work his way upwards, he started on a downward climb and now he is almost as close to the bottom as he could ever be. (Desai 26)

However, Sampath's grandmother is confident about his future. She says:

Wait and see! Even if it appears he is going downhill, he will come up out on the other side. Yes, on top of the world. He is just taking the longer route. (Desai 26)

Ammaji's view was in a complete contrast to the views of all family members, and as such everyone made a mockery of her words, leave aside believing it. But Sampath, in a very strange manner, proved his grandmother correct. In the story when he climbs the guava tree, Sampath becomes much popular.

Thus, the main character, Sampath, decides to spend his life in trees. "Rebellion reveals a sense of repulsion towards social impositions" (Armellino 76). Choice of living in trees forms a rebellion against the dominant ways of thinking. Sampath rebels against his father. He is a rebel though in a different way. Sampath's development as a child is much influenced by his mother. She is the real sufferer who cannot stand the rules of society her husband strongly respects and adheres to. Sampath's decision to climb up a guava tree and never go back is the rebellion his mother could not attempt. By doing this Sampath escapes from the comical confines of life. 
At a deeper level, the novel displays the theme of alienation. Sampath is a character of strange temperament. He is different from other people. His need, desires and feelings are different. His father does not understand all and always criticizes him. As a result, he suffers from a painful sense of displacement. A lost boy, frustrated by the indentured state of his life with a strictly structured society, runs away. But rather than running to a new city, he climbs a guava tree and decides to stay. His stay evolves into a state of sainthood, all because he read people's mail while working at the post office and thus can speak to the people about their private affairs. From this instance we can better understand the theme of alienation. However, scholar Elisa Armellino views this differently when she says, "From another point of view, it is also the character's achievement of a full coming into being" (81). In the impact of alienation the character realises his strength. She further says, "In this case, the climbing of tree is a metaphor for the re-discovery of the true self" (81).

Kiran Desai, through this novel, exhibited magic realism. The novel is full with magical imagery. It adds a powerful element to her writing. The beginning of the novel itself gives a little idea about it. Description of Kulfi, Sampath's mother, is magical. Throughout the novel, she expresses a sense of vague longing, and lonely sensation. At first, that desire takes the shape of food; she is famished throughout her pregnancy and becomes obsessed with food. As her pregnancy advances, she does not simply become heavy and uncomfortable, but rather, “. . . she seemed to be claiming all the earth's energy for herself, sapping it dry, leaving it withered, shriveled and yellow" (Desai 3). Kulfi represents the incarnate desire for meaning in life beyond the daily drudgery of going to work and returning home again, of going through the motions of a well-meaning life. Kulfi leaves the townspeople to their own doings, never integrating herself into the life of the bazaar or ingratiating herself to any of the people in town who hold positions of relative power, as was the norm with the other wives of the town. 
Magic realism continues with the character of Sampath. In fact, his whole existence is endowed with a sense of the supernatural. The scene of his birth is of almost mysterious and incredible kind. Use of supernatural in the last scene is quite remarkable. When the army men force Sampath to get down the guava tree, he disappears, and a big guava fruit is found in his place. Desai used magic realism to create a sense of supernatural.

The author introduces interesting characters in the plot - Sampath, Kulfi, his sister Pinky, Ammaji, Varmaji, brigadier, etc. Kiran Desai's portrayal of the character shows her admirable skill of art of characterization. She portrays Kulfi as a rather adamant character, having a consistent and enduring personality through the entire plot. People's reactions to seeing her, and the gossip, hints that she was already cast out and was being mocked by society. By the time Kulfi was completely infatuated with food and was drawing food on the walls of her house, she was thought to have existed in her own bizarre world, portrayed an independent and free bubble floating around the complex town of Shahkot. Desai introduces Sampath as the second character that existed independently of society, but as an indifferent and passive character who people talked little about as opposed to Kulfi. Sampath, though, is portrayed as a submissive character, yielding to society and consciously eclipsing himself as he becomes a celebrity for the people as Shahkot, being known as 'the monkey baba'. All these characters may make some impression of caricatures. However, they are constructed with admirable skill, and they delineated with such wit and affection that they insinuate themselves insidiously in our minds, even as they belong to an imaginary town of Shahkot. Desai also portrays a story of love, life, and family relationship. The story deals with the general conflict between generations and the conflict between children and parents.

So the novel reveals a strange and eccentric journey of a failed post-office clerk who achieves great popularity by becoming a 'Baba' when he starts spending his life on a guava tree. It's a very funny and engaging novel that moves from a comic tale to a strange close. 
Desai is a masterful dialogue writer, and she uses this skill to great effect in Hullabaloo in the Guava Orchard. She infuses the dialogue with local idioms and paints a vivid portrait of life in a small city in India. With a clear objective of writing a comic satire, she also makes a satirical attack against the creation of gurus in Indian society. Following the incidents happening at the guava orchard, the novel can also be categorized as a fable. In the conclusion I would like to quote Sunita Sinha. She says, "The novel derives its strength from the steady fluidity in which the story unfolds itself by use of brilliantly lucid images and a distinct choice of unaffected words and phrases and an eccentric set of characters" (xix). In all, the novel offers an imaginative and witty portrayal of the world. 


\section{Works Cited}

Armellino, Elisa. "Italo Calvino's The Baron in the Tree and Kiran Desai's Hullabaloo in the Guava Orchard: A Comparative Study." Critical Responses to Kiran Desai. Ed. Sunita Sinha and Bryan Reynolds. Atlantic, 2009. pp. 74-85.

"Book Summary: Hullabaloo in the Guava Orchard". Book Browse. N.p. n.d. Web. 15 April 2020. <https://www.bookbrowse.com/reviews/index.cfm/book_number/317/hullabalo o-in-the-guava-orchard >.

Desai, Kiran. Hullabaloo in the Guava Orchard. Faber \& Faber, 1998.

Sinha, Sunita and Reynolds, Bryan. Introduction. Critical Responses to Kiran Desai. Ed. Sinha \& Reynolds. Atlantic Publishers, 2009. pp. xv-xxx. 